\title{
THE ONTOGENY OF SHAPE DISPARITY in three species of Otariids (Pinnipedia: Mammalia)
}

\author{
Daniela Sanfelice ${ }^{1, *}$ and Thales R. O. De Freitas ${ }^{2}$
}

\begin{abstract}
We compared skull ontogenies in three otariid species to identify evolutionary novelties and to understand their relationships with diversity. The species studied were Arctocephalus australis, Callorhinus ursinus and Otaria byronia. We analyzed evolutionary changes in three parameters of developmental trajectories of skull shape: shape at the outset of ontogeny, allometric pattern, and the amount of change undergone over the course of ontogeny, which depends on its duration (the length of the ontogenetic vector) and on the rate of development. Initial shapes were always very different among the species and the distances between shapes increased with time, independently from size. Furthermore, when the complete samples were considered, all the ontogenetic trajectories were significantly different concerning the directions of the allometric vectors during ontogeny. Ontogenetic trajectories also differed significantly among almost all compared pairs, except for the trajectories of males of $A$. australis and C. ursinus. However, these differences are expected by chance (considering the range of angles within each sample). A similar pattern was found when the subadults were compared in pairs of species, as well as adult males of A. australis and $O$. byronia. The correlation found between ontogenies of juveniles was expected by chance, with exception of $C$. ursinus and $O$. byronia. The ontogenetic trajectory of $C$. ursinus is the shortest and that of $O$. byronia is the longest, with the latter being near the triple of the former. A. australis has an intermediary length of ontogenetic trajectory. Considering all three species, disparity increased significantly over ontogeny since the disparity of the adults is near double that between juveniles. However, the pattern of disparity did not change considerably during ontogeny. For any ontogenetical stage, O. byronia is the species that most contributed to the disparity of the group, followed by C. ursinus. Finally, ontogenies examined herein are clearly not constrained (almost every developmental parameter of shape that could evolve was observed) and perhaps the differences in patterns have additive effects in the differentiation of the ontogenies.
\end{abstract}

Resumo: Objetivou-se comparar as ontogenias do crânio de três espécies de Otariidae para identificar novidades evolutivas na forma a fim de entender as relações destas com a diversidade. As espécies estudadas foram Arctocephalus australis, Callorhinus ursinus and Otaria byronia. Analisaram-se mudanças evolutivas em três parâmetros das trajetórias de desenvolvimento da forma dos crânios: forma no início do desenvolvimento, padrão alométrico e a quantidade de mudanças - que depende da duração (tamanho do vetor ontogenético) e da taxa das mudanças. As formas iniciais mostraram-se sempre diferentes entre todas as espécies e as distâncias entre as formas aumentou com o tempo, independentemente do tamanho. Em acréscimo, ao considerar-se toda a amostra, todas as trajetórias mostraram-se significativamente diferentes no que concerne às direções dos vetores alométricos. As trajetórias ontogenéticas diferiram significativamente entre praticamente todos os pares comparados, exceto para as trajetórias de machos de A. australis e C. ursinus. Estas espécies não se revelaram mais diferentes do que seria esperado ao acaso (considerando a distribuição dos ângulos em cada amostra). Um padrão similar foi encontrado quando os subadultos foram comparados entre pares de espécies e também quando foram comparados machos adultos de A. australis e de O. byronia. As correlações entre as ontogenias dos juvenis das três espécies enfocadas tampouco diferiram mais entre si do que o esperado ao acaso, excetuando-se entre os juvenis de C. ursinus e O. Byronia. A trajetória ontogenética de C. ursinus é a mais curta e a de O. byronia a mais longa (quase o triplo daquela de C. ursinus). A. australis apresenta um tamanho de trajetória intermediário. Quando as três espécies foram analisadas conjuntamente, verificou-se um aumento da disparidade ao longo da ontogenia (a disparidade dos adultos foi praticamente o dobro daquela entre os juvenis) e o padrão de disparidade não se altera significativamente ao longo da ontogenia. Para qualquer estágio ontogenético, $O$. byronia é a espécie que mais contribui para a disparidade do grupo examinado, seguida de C. ursinus. Finalmente, as trajetórias examinadas aqui claramente não são constringidas e talvez a diferença entre os padrões apresente efeitos aditivos na diferenciação das ontogenias.

Keywords: Otariidae, ontogeny, skull, disparity, geometric morphometrics.

\section{Introduction}

Disparity and taxonomic diversity provide insights into the expansion and contraction of variety, and the relationship between these two aspects of diversity also have important implications for evolutionary mechanisms. Disparity is measured as the total variance among forms in morphological space (proportional to the mean squared distance among forms) (Foote, 1993). This quantity is a measurement of the range of morphologies in a given sample of organisms, as opposed to diversity, which is expressed in terms of number (and sometimes ranking) of taxa.

The concept of biological and ecological diversity is familiar. It can be assessed by a variety of indices, usually depending upon the number of taxa present in a given sample. A related concept is the absolute morphological variety of a group, its variance in shape or the amount of morphological space that it occupies (Foote, 1992). On the other hand, the concept of disparity refers to how much the members of a group of organisms are morphologically different from each

\footnotetext{
${ }^{1}$ Programa de Pós-graduação em Biologia Animal IB/UFRGS, Porto Alegre, RS, Brazil; Museu de Ciências Naturais/FZBRS. Av. Salvador França, 1427, Porto Alegre, 90690-000, RS, Brazil.

* Corresponding author, e-mail: daniela.sanfelice@fzb.rs.gov.br.

${ }^{2}$ Genetics Department, IB/UFRGS, Porto Alegre, RS, Brazil.
} 
other, and then geometric morphometry provides a very objective assessment for these differences (Foote, 1992). Furthermore, variation and disparity are similar terms related to the concept of variety, where disparity generally means the variety among a group. Disparity is the outcome of evolutionary processes and variation is the variety of individuals within a homogeneous group. Thus, it is the raw material to evolutionary processes (Zelditch et al., 2004).

The objective of this work is to compare ontogenies to identify divergent developmental features in the shape of the otariid skull with the purpose of understanding their relationships with diversity. The species studied were Arctocephalus australis Zimmermann, 1783, Callorhinus ursinus Linnaeus, 1758 and Otaria byronia Blainville, $1820^{3}$. Thus, we present a comparative study of the ontogeny of the skull of the two Otariidae species more frequently found on the coast of Rio Grande do Sul state, Brazil (A. australis and O. byronia). Callorhinus ursinus is also included because it is supposedly the extant otariid more closely related to the ancestral of this family (Berta et al., 2006). In this context, we analyzed evolutionary changes in three parameters of developmental trajectories of skull shapes: (1) shape at the outset of ontogeny, defined here as the starting point of the vector representing the ontogeny of shape; (2) allometric pattern and the direction of allometric vector in shape and space, and (3) the amount of change undergone over the course of ontogeny, which depends on the duration (the length of the ontogenetic vector) and rate of development.

That approach is justified by the fact that the study of disparity is a primordial step to understand how evolutionary novelties interact in those groups, which is particularly interesting considering the rapid (and poorly understood) radiation and speciation of the extant Otariidae (Demeré et al., 2003).

In addition, the shape disparity between different developmental stages was compared to check if the disparity level decreases during ontogeny (presence of novelties), which could indicate non-additive interactions between novelties (Zelditch et al., 2003a).

The selected focus was skull shape because these ontogenetic series are easily available and these data are especially well suited to studies of disparity (Zelditch et. al, 2003a). In addition, shape underlies the general statistical theory of modern shape analysis, the Procrustes distance. In fact, traditional morphometrics presents a major analytic problem caused by discrete characters: units of the same apparent magnitude are not necessarily equivalent (Zelditch et al., 2003a). However, any two samples that are separated by one unit of Procrustes distance differ from each other by the same amount as any other taxa. This aspect is important when the goal is to quantify the degree of difference among morphologies, especially when it concerns nonadditivity of the interacting causes of disparity. Otherwise, this distance can be traced directly to the modifications in the place of homologous landmarks the change in those locations is directly proportional to the difference in shape (Zelditch et al., 2003a).

\section{Material and Methods}

\section{Sampling}

Our samples comprise cross-sectional ontogenetic series of the skull of three otariid species: A. australis $(\mathrm{n}=76)$, C. ursinus $(\mathrm{n}=51)$ and O. byronia $(\mathrm{n}=84)$ (Appendix 1). We used the number of growth layer groups deposited in the dentine of the bisected canine as our estimate of chronological age (Schiavini, 1992) and the sutural ages to determine the ontogenetic stages (juvenile, subadults and adults) (Sivertsen, 1954). The analyses were performed considering species, sex and sutural age groups (juveniles, subadults and adults).

Our analyses were based on landmarks, discrete points that were recognizable and homologous on all species (and specimens) at different ages, in the study (Figure 1). The landmarks were chosen to provide the most comprehensive coverage of that view of the skull. Consistency of relative position, repeatability and coplanarity of the landmarks were also considered in the selection of these points. All landmarks were digitalized by one of the authors (D. Sanfelice). After that, the specimens were superimposed using the Generalized Least-Squares Procrustes superimposition (GLS).

\section{Defining Morphological space and measuring morphological diversity}

The approach here is to ordinate forms in a multidimensional morphospace and to base morphological differences on the array of points in morphospace (Cherry et al., 1982). Consequently, disparity is measured as the sum of univariate variances of all dimensions in morphospace, which is proportional to the mean squared Euclidean distance among points in morphospace (Van Valen, 1974).

The partial disparity is analogous to a variance, where the squared distances are taken relative to the overall centroid rather to the centroid of the subgroup. This permits access to the disparity contributions of subgroups. This has allowed morphological disparity analysis to address an issue that has long been addressed with taxonomic diversity data concerning the relative contributions of different subgroups to overall morphological disparity. The method of disparity partitioning allows an assessment of the relative contributions of different taxa to the morphological disparity of the larger group containing them.

\footnotetext{
${ }^{3}$ Our use of the specific name byronia follows Drehmer (2005), Gardner and Robbins (1995) and ICZN Opinion 1962 (2000).
} 


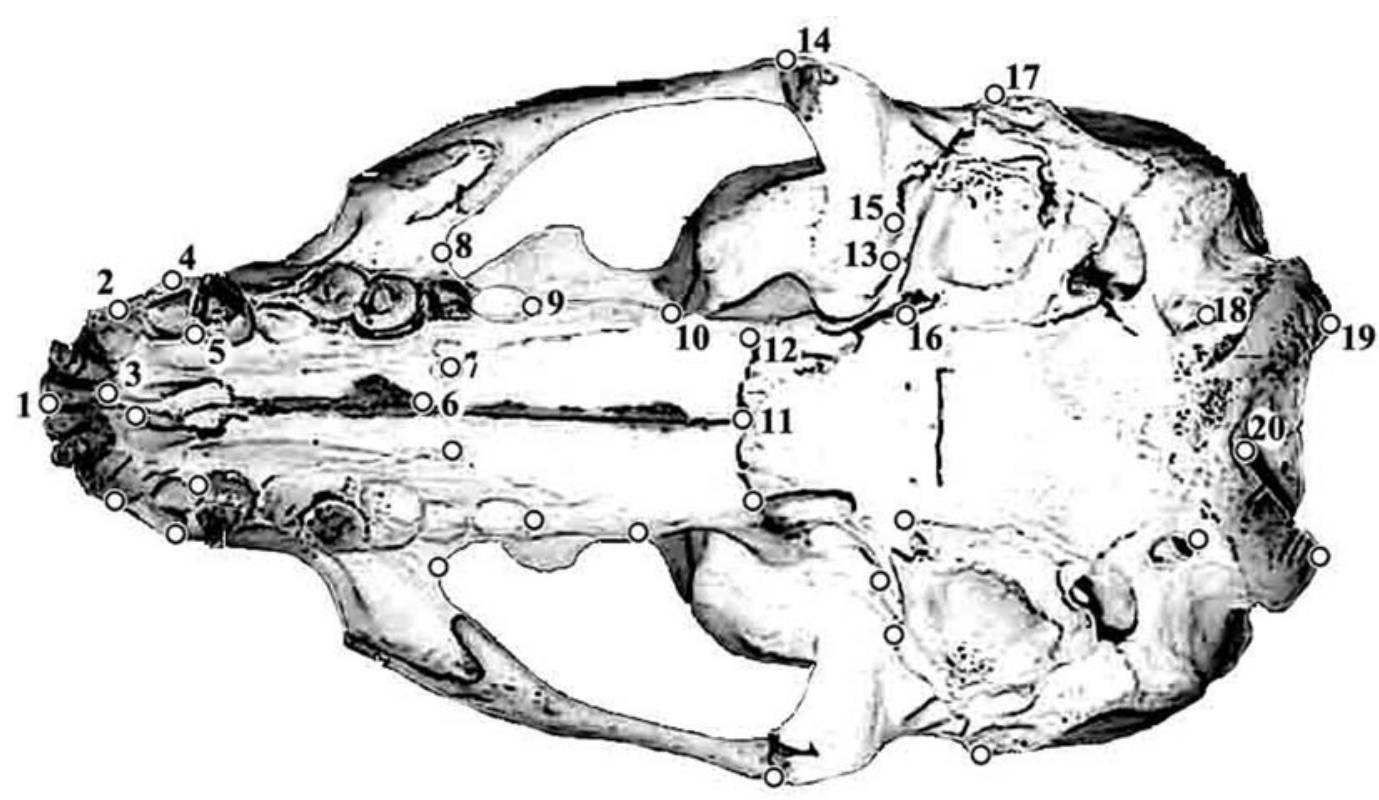

Figure 1. Landmarks shown on the ventral view of the skull of a juvenile of Otaria byronia. Descriptions of each landmark are given in Appendix 2.

\section{Estimation and Comparisons among the Initial Shapes}

The initial shape is estimated from the regression equation, which predicts the expected shape at each size or age. Here, we predicted the mean shape for each species at age zero. The sexes were pooled together considering that juveniles were not dimorphic in shape (Sanfelice and Freitas, 2008). Subsequently, the residuals from the regression were added to the predicted form, yielding a sample of shapes at each stage. Each individual specimen contributed with only one residual (i.e. the deviation of that individual from the predicted shape). To compare shapes, multivariate analysis of the variance (MANOVA) was performed and pairwise comparisons tested the differences between groups two-by-two. Otherwise, an experiment-wise error rate of 0.05 was maintained by dividing the number of unplanned comparisons (three) to obtain the critical a value of 0.016 (Bonferroni Correction). The misclassification rate of the discriminant function was also analyzed. The statistical significance of the pairwise differences was tested by a resampling-based F-test. The MANOVA and the misclassification rate were performed with CVAGen6j; pairwise F-tests were run in Two-Group6h. These programs belong to the Integrated Morphometrics Programs (Sheets, 2000) and they are freely available electronically at http://www.canisius.edu/;sheets / morphsoft.html.

\section{Comparisons of the Allometric Trajectories}

These parameters were assessed by multivariate regression of the partial warp plus the uniform component scores (dependent variable representing shape) on a measurement of geometric scale (the logarithm of the centroid size). For each species separately, the full set of shape variables was regressed on the independent variables considered. We assumed a linear relationship between shape and size since these estimates were based on linear regression.

\section{Estimates and Comparisons between Allometric Patterns}

The vector of allometric coefficients that describes morphogenesis is calculated using the multivariate regression of shape on size, as detailed above. To compare these vectors by multivariate analyses, we calculated the angle between them (the cosine of that angle is the vector correlation between the two ontogenetic trajectories of shape). That cosine was calculated as the inner product of vectors of allometric coefficients, normalized to the unit length. Thus, if two vectors pointed in the same direction, the angle between them would be equal to zero and the cosine would be 1 . Since it would be too strict to consider an angle of 0 as the null hypothesis, here the null hypothesis states that the angles between species are no larger than we would expect from the variation within a single species or group (some variation is expected because individuals of the same species do not have identical ontogenies of shape). The subject here is whether or not the uncertainty of the estimation of each species trajectory (due to sampling) is very large, making it impossible to reject the null hypothesis of any significant difference. To estimate the range of angles within each species in congruence with the datasets (and thus to calculate the imprecision of the trajectory due to sampling) we estimate the residuals from the multivariate regression in a way that each individual gives a multi- 
dimensional set of residuals describing its deviation from the expected shape at its size. Thus, a pair of bootstrap sets was constructed for species that will be used to calculate the angle between the trajectories in consideration. These pairs were constructed by resampling residuals (with replacement) and were randomly assigned to expected values of shape (derived from the original regression model) at values of the logarithm of centroid size (detected in the original data). This bootstrap approach is no more than a multivariate extension of the known procedure to estimation of uncertainties of regression slopes by resampling the covariance structure among variables (Efron \& Tibshirani, 1993). Finally, the angles between the trajectories derived from the two within-species bootstrap sets were estimated and this procedure was repeated $N$ times to produce a distribution of within-species angles. In the present study, we employed $N=100$. Since sample sizes were different among the species, the two bootstrap sets constructed from the species with largest sample size matched sample sizes of the two species in comparison (i.e. one set has the largest sample size of that species, while the other has the smallest sample size of the other species). The two bootstrap sets obtained from the data of the species with the smallest sample size have that sample size, since a bootstrap larger than the original data set cannot be constructed. If the interspecific angle exceeded the $95^{\text {th }}$ percentile of the within-species range of angles, the interspecific difference was considered to be statistically significant. The multivariate regressions were performed using Regress6k and the comparisons between ontogenetic trajectories were carried out using VecCompare, both programs freely available in the IMP series (Sheets, 2000).

\section{Estimations and Comparisons between the Lengths of} Ontogenetic Trajectories

The length of the ontogenetic trajectory of shape is a function of the rate of shape change and the duration of development. To estimate this length, the Procrustes distance between the average shape in the juvenile stage and the shape at maximum body size was calculated. Confidence limits were placed on this measurement by bootstrap, considering the variability among individuals at the same size and the uncertainty of the regression. That is, the residuals estimated from the regression were drawn with replacement at random and were added to the expected shape, generating a bootstrap data set for each species. In the sequence, the same regression model was fitted to the bootstrapped sets and the size correction was carried out on these sets. The result was a bootstrap set for each species that incorporated the uncertainty of regression. These calculations were performed by DisparityBox6g, another freely available program in the IMP series (Sheets, 2000).

Measurement of the Level of Disparity

The level of disparity was calculated according to Zelditch et al. (2003a) for the different ontogenetical stages in each species and sexes (adults) and among species. To test the significance of differences in levels of disparity, we used the bootstrapping procedure explained in the previous section, since the analyses presented here were based on standardized data and the tests should take into account the uncertainties of the regression. Considering that one of the difficulties found in calculating the level of disparity was the differences in shape related to differences in size (allometry) and its influence on the disparity, the level of disparity was studied with and without correction for size. Therefore, we fitted a regression model to the data, determining the residuals and producing size-standardized data set. In the study without size correction, we measured disparity with correction to the mean size of each subsample and with correction using the same size for the two samples. The Partial Disparity, which is the contribution to disparity of each subsample analyzed, was calculated using Disparity Box6g (Sheets, 2000).

\section{Analysis of the Pattern of Disparity}

The dimensions and the distribution of shapes along the series where shapes are most disparate were described by principal components analysis, using the software PCAGen6n (Sheets, 2000). Such examinations are relevant because distinct ontogenetic stages may have the same level of disparity but present a different pattern, which hide the dynamic nature of disparity (Zelditch et al, 2003b). The patterns were examined for each subsample separately with the aim of finding one biological explanation to the direction of dominant variation within shape space (in addition to the fact that the morphospace resultant is different from sample to sample). The significance of the principal components was tested by Anderson's test.

The sub-samples compared were: juveniles (specimens with sutural age between 9 and 10, including newborn and animals between 0 or 1 year of age), subadults (specimens with sutural ages between 11 and 18) and adults (specimens with sutural ages superior to 18). The adults were separated by sex, due to the dimorphism in the adult shape.

\section{Results and Discussion}

\section{Comparisons among the Initial Shapes}

All pairwise F-tests among species showed statistically significant differences in the initial shape $(p=0.01)$, even after Bonferroni corrections for three comparisons $(p=0.05)$. In addition, no specimens $(n=47)$ were incorrectly classified by the discriminant function. The pairwise distances between means are presented (Tables 1 and 2), suggesting a labile aspect in the initial shape of the otariid skull.

Performing the same analysis for the other ontogenetic phases, we detected that the differences tend to increase during ontogeny and that size does not have a great influence in the amount of difference. 
Table1. Procrustes distances among the average initial shapes of Arctocephalus australis, Callorhinus ursinus and Otaria byronia.

\begin{tabular}{lccc}
\hline \hline & A. australis & C. ursinus & O. byronia \\
\hline \hline A. australis & 0 & 0.0685 & 0.1003 \\
C. ursinus & & 0 & 0.1444 \\
O. byronia & & & 0 \\
\hline \hline
\end{tabular}

All pairwise differences are statiscally significant for the Bonferroni-adjusted value of $\alpha=0.05$.

We compared shapes with different standardizations (e.g. standardized by the minimum size of all specimens, by the maximum size of all the females, by the maximum size of all the males, by the range of size of the females of each correspondent species or even standardized by the range of size of the males of each corresponding species).

\section{Allometric Patterns}

When complete samples were considered, all the ontogenetic trajectories were significantly different concerning the directions of the allometric vectors during ontogeny. Here, the allometric patterns for each sex were presented separately, since patterns are distinct between males and females of the same species (Sanfelice and Freitas, 2008). Ontogenetic trajectories differed significantly among almost all compared pairs, except for the trajectories of males of A. australis and
Table 3. Comparisons among ontogenetic trajectories of Arctocephalus australis, Callorhinus ursinus and Otaria byronia. Vector correlations are above the diagonal, angles (in degrees) are below the diagonal.

\begin{tabular}{cccc}
\hline \hline & \multicolumn{3}{c}{ ᄋ } \\
\hline \hline & A. australis & C. ursinus & O. byronia \\
\hline \hline A. australis & - & 0.766044 & 0.785857 \\
C. ursinus & $\mathbf{4 0}$ & - & 0.758134 \\
O. byronia & $\mathbf{3 8 . 2}$ & $\mathbf{4 0 . 7}$ & - \\
\hline \hline \multicolumn{4}{c}{ ○' } \\
\hline \hline & A. australis & C. ursinus & O. byronia \\
\hline \hline A. australis & - & 0.772734 & 0.786935 \\
C. ursinus & 39.4 & - & 0.658689 \\
O. byronia & $\mathbf{3 8 . 1}$ & $\mathbf{4 8 . 8}$ & - \\
\hline \hline
\end{tabular}

Angles statistically significantly different from $0^{\circ}$ are in bold.

C. ursinus. The differences presented by this group are expected by chance considering the range of angles within each sample (Table 3). A similar pattern was observed when the subadults were compared between pairs of species, as well as for adult males of A. australis and O. byronia. Differences observed in juveniles were expected by chance (correlation between ontogenies in that phase was equal to one), with exception of C. ursinus and O. byronia, where angles ranged from $38.2^{\circ}$ to $40.7^{\circ}$ in females and from $38.1^{\circ}$ to $48.8^{\circ}$ in males. The most divergent trajectories found were those of $C$. ursinus and $O$. byronia for both sexes.

Table 2. Procrustes distances among the average shapes of Arctocephalus australis, Callorhinus ursinus and Otaria byronia.

\begin{tabular}{lcccc}
\hline \hline A. australis $x$ C. ursinus & DISTANCE & $95 \%$ CI & ST. MINIMUM & $95 \%$ CI \\
\hline \hline JUVENILES & 0.0685 & $0.0577-0.0861$ & 0.0719 & $0.0628-0.0821$ \\
SUBADULTS & 0.0647 & $0.058-0.08$ & 0.0592 & $0.0551-0.0674$ \\
ADULT FEMALES & 0.0673 & $0.0552-0.0793$ & 0.0543 & $0.0478-0.065$ \\
ADULT MALES & 0.0497 & $0.0444-0.0567$ & 0.0573 & $0.909-0.1153$ \\
\hline \hline A. australis $x$ O. byronia & DISTANCE & $95 \%$ IC & ST. MINIMUM & $95 \%$ IC \\
\hline \hline JUVENILES & 0.0996 & $0.930-0.1125$ & 0.1063 & $0.0989-0.1233$ \\
SUBADULTS & 0.1444 & $0.1353-0.1528$ & 0.1373 & $0.1299-0.1464$ \\
ADULT FEMALES & 0.1387 & $0.1288-0.1459$ & 0.142 & $0.1345-0.1488$ \\
ADULT MALES & 0.1683 & $0.1578-0.1795$ & 0.1662 & $0.1532-0.1747$ \\
\hline \hline C. ursinus $x$ O. byronia & DISTANCE & $95 \%$ IC & ST. MINIMUM & $95 \%$ IC \\
\hline \hline JUVENILES & 0.1445 & $0.1355-0.1566$ & 0.1406 & $0.1356-0.1487$ \\
SUBADULTS & 0.1842 & $0.1683-0.1989$ & 0.16 & $0.1491-0.1703$ \\
ADULT FEMALES & 0.1859 & $0.1747-0.1969$ & 0.1717 & $0.1615-0.1807$ \\
ADULT MALES & 0.1921 & $0.1839-0.2014$ & 0.1745 & $0.1652-0.1841$ \\
\hline \hline
\end{tabular}

All pairwise differences are statiscally significant for the Bonferroni-adjusted value of $\alpha=0.05$. Distance is the Partial Procrustes Distance; $95 \%$ CI is the confidence interval; St. minimum is the PPD when the samples were standardized to the respective smallest size. 
It may appear that the three species examined were more similar than expected by chance (i.e. the correlation is higher than zero) but they differed significantly (i.e. the correlations were lower than one). Additionally, the differences in the ontogenetic transformations of shape were visually conspicuous between sexes and overall between species (Figure 2).

\section{Lengths of Ontogenetic Trajectories}

The ontogenetic trajectory of C. ursinus was the shortest, while the longest was observed for O. byronia. Arctocephalus australis had an intermediary length of ontogenetic trajectory. In the three species, the females had the longest trajectories, but the confidence intervals of lengths of trajectories overlapped between the sexes of the same species. On the other hand, the lengths were significantly different between species (considering the sex pooling together or separately) (Table 4).

\section{Shape disparity}

In $A$. australis the disparity increased gradually and the disparity between the two sexes was the smallest in the adults, especially when we corrected for size (Table 5). The disparity between juveniles and subadults was nearly four times higher in C. ursinus than in A. australis, but the level of disparity between the different ontogenetic stages was more or less constant (the disparity between adults was nearly four times higher in C. ursinus that it was observed for $A$. australis) (Table 5). In the sea lion O. byronia (the species with a high level of disparity between males and females) the high level of disparity was found relatively early in ontogeny, between juveniles and subadults (Table 5 and 6). The subadults versus adult females presented the smallest disparity in morphology. In addition, it was observed that the disparity between the juveniles and the other ontogenetic stages was extremely striking, increasing gradually (Table 5). Moreover, standardization was not effective due to the small difference in size observed among the stages compared in the same species (Tables 5 and 6). For the sample comprising all three species, disparity increased significantly throughout ontogeny, since the disparity of the adults is near double the disparity found between juveniles (Table 7). Otherwise, for any ontogenetical stage, $O$. byronia is the species that most contributed to the group disparity, followed by C. ursinus (Table 8).

Comparing the two species of fur seals, the level of disparity is nearly static over the course of ontogeny, especially in females (but with some increment when we analyzed the disparity applying the size correction). In males we observed a decrease in disparity (Table 8 ). When $A$. australis and O. byronia were compared, the level of disparity increased early in ontogeny, but after the subadult stages it was almost stable. The disparity between C. ursinus and
Arctocephalus australis

(fem ales)

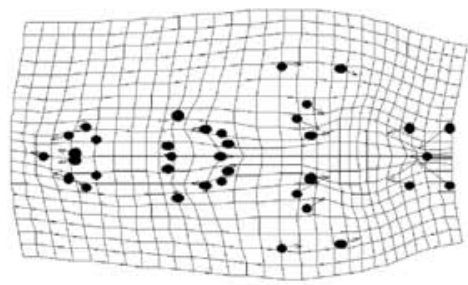

Callorhinus ursinus (males)

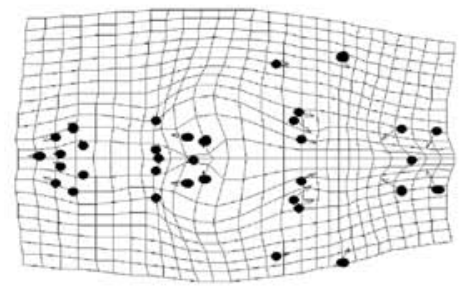

Arctocephalus australis

(males)

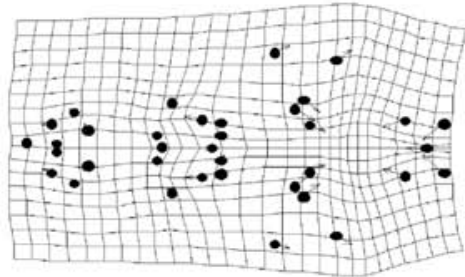

Otaria byronia

(females)

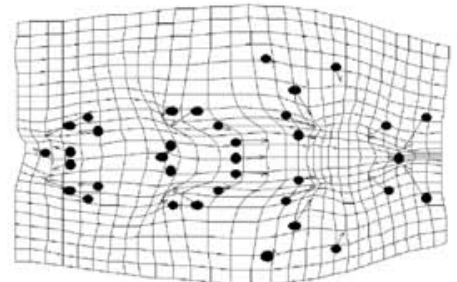

Callorhinus ursinus

(females)

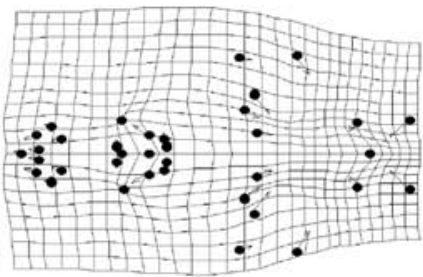

Otaria byronia

(males)

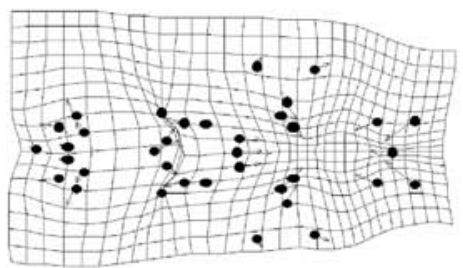

Figure 2. Ontogenetic transformations in shape. Each diagram depicts the regression of shape on log-transformed centroid size as a Cartesian transformation using the thin-plate spline. 
O. byronia was high and constant during the development, with a very inconspicuous increment in the early ontogeny. In addition, this level was almost two times higher in adults of both sexes when the size correction was performed. The disparity between the sea lion and the other two species was similar, considering the range of the confidence intervals (and when the size correction was not applied).

\section{Pattern of shape disparity}

When we considered the three species together, the pattern of disparity did not show a considerably change during ontogeny (Figure 3). In the variance of juvenile shape, two significant components were found: the first separate the fur seals species from the sea lion species (Figure 3A). Otaria byronia, which presents high scores in that component, is differentiated from those with low scores by the great extension of the palate (and by consequence, the shorter choanes), the deepening of the braincase, and the comparison of the braincase with the rostrum. The second component describes the enlargement of the rostrum and the forward displacement of the choanes, but the most conspicuous pattern of changes in shape explained by this component is the postero-distal expansion lateral and posterior to the braincase. Arctocephalus australis had the lowest scores in that component and C. ursinus the highest. In subadults, the first principal component is responsible for the enlargement of the rostrum and the mastoid process region, and the second principal component expressed the enlargement of the posterior region of the bone palate. In adults of both sexes, the enlargement in length and width is expressed largely by the first principal component (except in the condyle region), and the second principal component is related to changes in the posterior regions of the bone palate (females) or modifications in the posterior regions of the alveolar process (males).

Table 4. Lengths of ontogenetic trajectories in units of Procrustes distance for Arctocephalus australis, Callorhinus ursinus and Otaria byronia.

\begin{tabular}{cccc}
\hline \hline SPECIES & ALL SPECIMENS $(95 \%$ CI $)$ & 9 $(95 \%$ CI $)$ & o $(95 \%$ CI $)$ \\
\hline \hline A. australis & $0.0099(0.0084-0.0119)$ & $0.0084(0.0066-0.0106)$ & $0.0062(0.0052-0.0075)$ \\
C. ursinus & $0.0053(0.0040-0.00078)$ & $0.0059(0.0033-0.0081)$ & $0.0038(0.0020-0.0067)$ \\
O. byronia & $0.0184(0.0163-0.0217)$ & $0.0162(0.0131-0.0230)$ & $0.0134(0.0106-0.0167)$ \\
\hline \hline
\end{tabular}

The confidence intervals are in parentheses.

Table 5. Level of disparity among ontogenetic and/or sex groups of Arctocephalus australis, Callorhinus ursinus and Otaria byronia.

\begin{tabular}{cccc}
\hline \hline & A. australis & C. ursinus & O. byronia \\
\hline \hline JUVENILES X SUBADULTS & $0.00023(0.00027-0.00077)$ & $0.00117(0.00069-0.00264)$ & $0.00415(0.00320-0.00077)$ \\
& $0.0017(0.0009-0.0034)$ & $0.0028(0.0012-0.0064)$ & $0.0111(0.0087-0.0218)$ \\
JUVENILES X ADULT FEMALES & $0.00212(0.00178-0.00280)$ & $0.00163(0.00116-0.00289)$ & $0.00592(0.00520-0.00830)$ \\
& $0.0051(0.0038-0.0076)$ & $0.0035(0.0026-0.0055)$ & $0.0145(0.0123-0.0261)$ \\
JUVENILES X ADULT MALES & $0.00227(0.00186-0.003)$ & $0.00316(0.00239-0.00450)$ & $0.00934(0.00740-0.01289)$ \\
& $0.0071(0.0058-0.0104)$ & $0.0063(0.0050-0.0084)$ & $0.0197(0.0165-0.0300)$ \\
SUBADULTS X ADULT FEMALES & $0.00116(0.00091-0.00197)$ & $0.00116(0.00091-0.00197)$ & $0.00033(0.00029-0.00076)$ \\
& $0.0016(0.0013-0.0025)$ & $0.0016(0.0013-0.0025)$ & $0.0008(0.0006-0.0016)$ \\
SUBADULTS X ADULT MALES & $0.00139(0.00112-0.00208)$ & $0.00128(0.00101-0.00243)$ & $0.00172(0.00128-0.00274)$ \\
& $0.0034(0.0023-0.0048)$ & $0.0018(0.0010-0.0041)$ & $0.0030(0.0024-0.0042)$ \\
\hline ADULT FEMALES X ADULT MALES & $0.00037(0.00038-0.00081)$ & $0.00128(0.00105-0.00151)$ & $0.00146(0.00108-0.00253)$ \\
& $0.0013(0.001-0.0027)$ & $0.0019(0.0012-0.0034)$ & $0.0025(0.0019-0.0040)$ \\
\hline FEMALES X MALES & $0.00011(0.00015-0.00045)$ & $0.00035(0.00025-0.001)$ & $0.0005(0.00041-0.00133)$ \\
\hline
\end{tabular}

The values in the first line of each case are the unstandarized levels of disparity and the values in the second line are the corresponding level with the samples standardized with respect to size. The numbers in parentheses are the confidence intervals. 
Table 6. Level of disparity (distance-based disparity based on the group means, working with all loaded groups-bootstrapped size correction between males and females) between males and females of Arctocephalus australis, Callorhinus ursinus and Otaria byronia.

\begin{tabular}{lccc}
\hline \hline & A. australis & C. ursinus & O. byronia \\
\hline $\begin{array}{l}\text { Standandized for the } \\
\text { minimum size }\end{array}$ & $0.0172(0.0105-0.0376)$ & $0.0214(0.0171-0.0542)$ & $0.0753(0.0539-0.1212)$ \\
$\begin{array}{l}\text { Standardized for the } \\
\text { maximum size of the females }\end{array}$ & $0.0129(0.0098-0.0282)$ & $0.0165(0.0110-0.0389)$ & $0.0246(0.0154-0.0381)$ \\
$\begin{array}{l}\text { Standardized for the } \\
\text { maximum size of the males }\end{array}$ & $0.0119(0.0082-0.0239)$ & $0.0154(0.0122-0.0406)$ & $0.0224(0.0153-0.0376)$ \\
$\begin{array}{l}\text { Standardized for the range of } \\
\text { size of the females }\end{array}$ & $0.0058(0.0045-0.0076)$ & $0.0061(0.0036-0.0088)$ & $0.0150(0.0123-0.0194)$ \\
$\begin{array}{l}\text { Standardized for the range of } \\
\text { size of the males }\end{array}$ & $0.0046(0.0037-0.0060)$ & $0.0079(0.0051-0.0115)$ & $0.0098(0.0083-0.0123)$ \\
\hline \hline
\end{tabular}

The numbers in parentheses are the confidence intervals.

Table 7. Shape disparity, measured as the square root of the average of the squared distances between the mean shape of each species and the centroid of Arctocephalus australis, Callorhinus ursinus and Otaria byronia. Confidence intervals are obtained by resampling.

\begin{tabular}{|c|c|c|c|c|c|c|c|c|}
\hline GROUPS & $\begin{array}{l}\text { JUVENILE } \\
\text { DISPARITY }\end{array}$ & $\begin{array}{l}\text { 95 }{ }^{\mathrm{TH}} \text { PERCENTILE } \\
\text { OF THE WITHIN- } \\
\text { SPECIES RANGE }\end{array}$ & $\begin{array}{l}\text { SUBADULT } \\
\text { DISPARITY }\end{array}$ & $\begin{array}{c}95^{\mathrm{TH}} \\
\text { PERCENTILE OF } \\
\text { THE WITHIN- } \\
\text { SPECIES } \\
\text { RANGE } \\
\end{array}$ & $\begin{array}{l}\text { 오 ADULT } \\
\text { DISPARITY }\end{array}$ & $\begin{array}{c}9^{\mathrm{TH}} \\
\text { PERCENTILE OF } \\
\text { THE WITHIN- } \\
\text { SPECIES RANGE }\end{array}$ & $\begin{array}{l}\text { " ADULT } \\
\text { DISPARITY }\end{array}$ & $\begin{array}{c}9^{\mathrm{TH}} \\
\text { PERCENTILE OF } \\
\text { THE WITHIN- } \\
\text { SPECIES } \\
\text { RANGE } \\
\end{array}$ \\
\hline $\begin{array}{c}\text { All } \\
\text { species }\end{array}$ & $\begin{array}{c}0.00603 \\
0.006\end{array}$ & $\begin{array}{c}0.0054-0.0073 \\
0.0056-0.012\end{array}$ & $\begin{array}{l}0.0098 \\
0.0089\end{array}$ & $\begin{array}{l}0.0089-0.0113 \\
0.0074-0.0108\end{array}$ & $\begin{array}{l}0.0097 \\
0.0116\end{array}$ & $\begin{array}{c}0.00885-0.01074 \\
0.0102-0.0138\end{array}$ & $\begin{array}{c}0.01128 \\
0.0123\end{array}$ & $\begin{array}{l}0.0104-0.0124 \\
0.0109-0.0145\end{array}$ \\
\hline $\begin{array}{c}\text { A. } \\
\text { australis } \\
\mathrm{x} \\
\mathrm{C} . \\
\text { ursinus }\end{array}$ & $\begin{array}{c}0.00266 \\
0.0026\end{array}$ & $\begin{array}{c}0.0022-0.004 \\
0.0016 \text { to } 0.0046\end{array}$ & $\begin{array}{l}0.0021 \\
0.0015\end{array}$ & $\begin{array}{l}0.0016-0.0032 \\
0.0010-0.0032\end{array}$ & $\begin{array}{l}0.0027 \\
0.0038\end{array}$ & $\begin{array}{c}0.00175-0.00352 \\
0.0028-0.0065\end{array}$ & $\begin{array}{c}0.00124 \\
0.0022\end{array}$ & $\begin{array}{c}0.001-0.0017 \\
0.0016-0.0037\end{array}$ \\
\hline $\begin{array}{c}\text { A. } \\
\text { australis } \\
\mathrm{x} \\
\text { O. byronia }\end{array}$ & $\begin{array}{c}0.00497 \\
0.056\end{array}$ & $\begin{array}{l}0.0043-0.0071 \\
0.0042-0.0112\end{array}$ & $\begin{array}{l}0.0104 \\
0.0104\end{array}$ & $\begin{array}{l}0.0095-0.0115 \\
0.0094-0.0119\end{array}$ & $\begin{array}{c}0.0096 \\
0.01\end{array}$ & $\begin{array}{c}0.00878-0.01075 \\
0.0081-0.0132\end{array}$ & $\begin{array}{c}0.01417 \\
0.0134\end{array}$ & $\begin{array}{l}0.0126-0.0162 \\
0.0105-0.0167\end{array}$ \\
\hline $\begin{array}{l}\text { C. ursinus } \\
\quad \mathrm{x} \\
\text { O. byronia }\end{array}$ & $\begin{array}{c}0.01047 \\
0.0099\end{array}$ & $\begin{array}{l}0.0095-0.0125 \\
0.0086-0.0156\end{array}$ & $\begin{array}{l}0.0169 \\
0.0147\end{array}$ & $\begin{array}{l}0.0146-0.0198 \\
0.0113-0.0187\end{array}$ & $\begin{array}{l}0.0172 \\
0.0210\end{array}$ & $\begin{array}{c}0.01551-0.01989 \\
0.0159-0.0261\end{array}$ & $\begin{array}{c}0.01846 \\
0.0212\end{array}$ & $\begin{array}{l}0.0168-0.0208 \\
0.0184-0.0243\end{array}$ \\
\hline
\end{tabular}

In the first line the disparity is presented without correction for size and in the second line the level of disparity is corrected for size, using a different size for each subsample.

In this context, we could observe that those early ontogenies (allometric patterns) were similar, with early stages overlapping in shape space. By contrast, subadults compose a confuse age group that could, sometimes, affect the clarity of the results with its heterogeneity and high variance. In fact, it is important to highlight that mean shape of female and male subadults was close to the significance level $(\mathrm{p}=0.055)$ in O. byronia, which increased the heterogeneity of this subgroup.

Ontogenies examined herein were clearly not constrained: almost every developmental parameter of shape that could evolve was observed. The species differed in the initial and later shape of the skull, in the length of the ontogenetic trajectories, and in the allometric pattern. Thus, we observed a complex scenario where it was difficult to establish a relationship between the developmental processes with the phylogeny, mainly because we had sampled only three species. It may be possible that if all species in the family were examined we would have been able to determine the causal relations between ontogeny and phylogeny in otariids. Thus, it would be very interesting to analyze the relevance of evolution and development in the history of otariids. Since the species did not conserve the same ontogenetic trajectory, their evolution cannot be explained only by a heterochronic hypothesis.

The strongest differences in the repatterning of the allometry occur in the later ontogeny, but $C$. ursinus and $O$. byronia are extremely different during the entire process. The observed result where the disparity is higher when all the species are pooled together was logical. Similarly, the high partial contribution to disparity by the sea lion is congruent with all the other results regarding the comparisons between shapes in these species. 
Table 8. Contributions to the disparity for each species, with and without size correction.

\begin{tabular}{|c|c|c|c|c|c|}
\hline & \multicolumn{2}{|c|}{ PARTIAL DISPARITY } & \multirow{2}{*}{$\begin{array}{c}\text { SE } \\
0.00143\end{array}$} & \multirow{2}{*}{$\begin{array}{r}\text { PD WITH SIZE } \\
\text { CORRECTION }\end{array}$} & \multirow{2}{*}{$\begin{array}{c}\text { SE } \\
0.00115\end{array}$} \\
\hline JUVENILES & $A a$ & 0.00053 & & & \\
\hline & $\mathrm{Cu}$ & 0.00236 & 0.00136 & 0.00216 & 0.00123 \\
\hline & $O b$ & 0.00314 & 0.00150 & 0.00314 & 0.00104 \\
\hline \multirow[t]{3}{*}{ SUBADULTS } & $A a$ & 0.00089 & 0.00259 & 0.00101 & 0.00217 \\
\hline & $\mathrm{Cu}$ & 0.00307 & 0.00246 & 0.00242 & 0.00231 \\
\hline & $\mathrm{Ob}$ & 0.00587 & 0.00262 & 0.00544 & 0.00218 \\
\hline \multirow[t]{3}{*}{ ADULT우 } & $A a$ & 0.00072 & 0.00256 & 0.00071 & 0.00325 \\
\hline & $\mathrm{Cu}$ & 0.00327 & 0.00271 & 0.00439 & 0.00263 \\
\hline & $\mathrm{Ob}$ & 0.00574 & 0.00232 & 0.00648 & 0.00356 \\
\hline \multirow[t]{3}{*}{ ADULT $\sigma^{\circ}$} & $A a$ & 0.00136 & 0.00344 & 0.00108 & 0.00343 \\
\hline & $\mathrm{Cu}$ & 0.00279 & 0.00274 & 0.00370 & 0.00327 \\
\hline & $\mathrm{Ob}$ & 0.00713 & 0.00271 & 0.00747 & 0.00343 \\
\hline
\end{tabular}

$A a=$ Arctocephalus australis; $\mathrm{C} u=$ Callorhinus ursinus; $\mathrm{Ob}=$ Otaria byronia; $\mathrm{PD}=\mathrm{Partial}$ Disparity; SE=Standard error.

Concomitantly with the allometric repatterning, the lengths of the ontogenetic trajectories are also different; thus, complex changes are acting in the evolving ontogenies of these otariid species. However, the impact of each evolutionary pattern on disparity (counterbalance or amplification) is difficult to design without modeling hypothetical ontogenies.

The hypothesis of amplification predicts that the interaction among several novelties enhances disparity above the level we would anticipate for their separate effects while the hypothesis of counterbalancing predicts that the interaction among several novelties diminishes the impact of combined novelties. The most probable one is the occurrence of amplifications, since the ontogeny is not constrained and we did not fince evidence of counter-balancing in the disparity, which tended to increase during ontogeny.

\section{Acknowledgements}

Work by D. Sanfelice was partially supported by a fellowship of Coordenadoria de Aperfeiçoamento Pessoal (CAPES), Conselho Nacional de Desenvolvimento Científico e Tecnológico (CNPq), Fundação de Amparo à Pesquisa do Rio Grande do Sul (FAPERGS) and by the Society for Marine Mammalogy. We thank E. A. Crespo, A. Lebas, J. Patton, D. Long, L. H. Cappozzo, P. C. Simões-Lopes and GEMARS for access to the scientific collections; L. R. de Oliveira for access to the ages of some specimens of Arctocephalus australis; D. M. M. M.
Schiller and E. A. Crespo for the help in the age analysis and L. A. Valério and E. Quadros for the help with the figures.

\section{References}

Berta, A., Sumich, J.L. And Kovacs, K.M. (1999) Marine Mammals - Evolutionary Biology. Academic Press, New York. 547 p.

Cherry, L.M., Case, S.M., KunKel, J.G., Wyles, J.S. And Wilson, A.C. (1982) Body shape metrics and organismal evolution. Evolution 36: 914-933.

Demeré, T.A., Berta, A. And AdAm, P. (2003) Pinnipedimorph evolutionary biogeography. Bulletin American Museum of Natural History 279: 32-76.

DREHMER, C.J. (2005) Variação geográfica em Otaria byronia (de Blainville, 1820) (Pinnipedia, Otariidae) com base na morfometria sincraniana. Ph.D. Thesis. Universidade Federal do Rio Grande do Sul. Porto Alegre, RS, Brazil. 202 p.

EFron, B. AND Tibshirani, R.J. (1993) An introduction to the bootstrap. Chapman and Hall, New York. 436 p.

Fооте, M. (1992) Rarefaction analysis of morphological and taxonomic diversity. Paleobiology 18: 1-16.

Foote, M. (1993) Discordance and concordance between morphological and taxonomic diversity. Paleobiology 19: 185-204.

Gardner, A.L. And Robbins, C.B. (1999) Case 3058. Arctocephalus F. Cuvier, 1826 and Callorhinus Gray, 1859 (Mammalia, Pinnipedia): proposed conservation by the designation of Phoca pusilla Schreber, [1775] as the type species of Arctocephalus; and Otaria Péron, 1816 and Eumetopias Gill, 1866: proposed conservation by the designation of Phoca leonina Molina, 1782 as the type species of Otaria. Bulletin of Zoological Nomenclature 56: 136-141. 


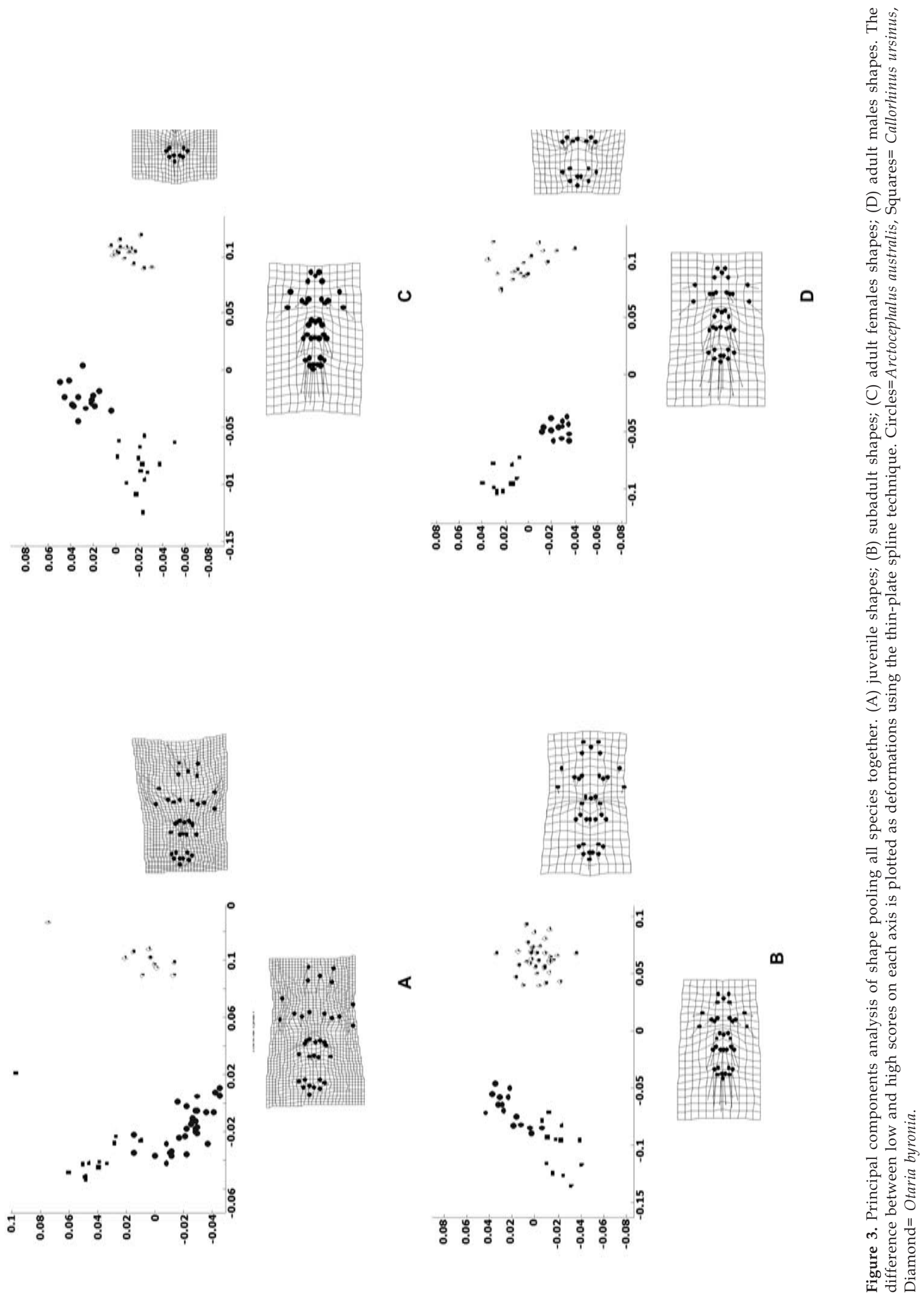


International Comission of Zoological Nomenclature. Opinion 1962 (2000) Arctocephalus F. Cuvier, 1826 and Callorhinus Gray, 1859 (Mammalia, Pinnipedia): proposed conservation by the designation of Phoca pusilla Schreber, [1775] as the type species of Arctocephalus; and Otaria Péron, 1816 and Eumetopias Gill, 1866: proposed conservation by the designation of Phoca leonina Molina, 1782 as the type species of Otaria. Bulletin of Zoological Nomenclature 57: 193-195.

Sanfelice, D. and Freitas, T.R.O. (2008) A comparative description of dimorphism in skull ontogeny of Arctocephalus australis, Callorhinus ursinus and Otaria byronia (Pinnipedia: Otariidae). Journal of Mammalogy 89: 336-346.

Schiavini, A.C., Lima, M.M and Batallés, L.M. (1992) Growth structures of maxillary canines of the Southern fur seal (Arctocephalus australis). Marine Mammals Science 8: 89-93.

SHEETS, D.H. (2000) Integrated Morphometric Softwares (IMP) Mathworks, MATLAB6. The Mathworks, Natick, Mass. http:/ /www.canisius.edu/ sheets/morphsoft.html.

SIVERTSEN, E. (1954) A survey of the eared seals (family Otariidae) with remarks on the Antarctic seals colected by M/K "Norvegia" in 1928-1929. Det Norske Videnskaps-Akademi 36: 1-76.

VAn Valen, L. (1974) A natural model for the origin of some higher taxa. Journal of Herpetology 8: 109-121.

Zelditch, M.L.; Swiderski, D.L., Sheets, D.H., ANd FinK, W.L. (2004) Geometric Shape Analysis for Biologists: A Primer. Academic Press, NY.

Zelditch, M.L.; Lundrigan, B.L.; SheETS, D.H. AND THEOdore, G. JR. (2003a) Do precocial mammals develop at a faster rate? A comparison of rates of skull development in Sigmodon fulviventer and Mus musculus domesticus. Journal of Evolutionary Biology 16:708-720.

Zelditch, M.L.; Sheets H.D. And FinK, W.L. (2003b) The ontogenetic dynamics of shape disparity. Paleobiology 29: 139-156. 


\section{APPENDIX 1}

\section{LISTING OF THE SPECIMENS EXAMINED}

Coll. $\mathrm{N}^{\circ}=$ Collection Number; $\mathrm{CS}=$ Centroid Size in units of centroid size $(\mathrm{cm}) ; \mathrm{CCB}=$ Skull Total Length (condylobasal length); Sut. Age= Sutural Age; Age= age in years.

Institution Acronyms: AMNH= American Museum of Natural History (New York, USA); CAS= California Academy of Sciences (San Francisco, USA); CNP= Centro Nacional Patagónico (Puerto Madryn, Argentina); FCIEN= Facultad de Ciencias (Montevideo, Uruguay); GEMARS= Grupo de Estudos de Mamíferos Marinhos (Porto Alegre, Brazil); LAMAMA= Laboratorio de Mamíferos Marinos (Puerto Madryn, Argentina); MACN= Museu Argentino de Ciencias Naturales Bernardino Rivadavia (Buenos Aires, Argentina); MCN= Museu de Ciências Naturais da Fundação Zoobotânica do Rio Grande do Sul (Porto Alegre, Brazil); MZV= Museu de Zoologia de Vertebrados (Montevideo, Uruguay); MVZ= Museum of Vertebrate Zoology (Berkeley, USA); NMNH= National Museum of Natural History (Washington D.C.); UAM= University of Alaska Museum; UFSC= Universidade Federal de Santa Catarina (Florianópolis, Brazil); UMICH= University of Michigan (Ann Arbor, USA). $\left({ }^{*}\right)$ Pictures by Dr. Sylvia Brunner (Alaska University Museum); (\#) Information available only upon request.

Arctocephalus australis

\begin{tabular}{|c|c|c|c|c|}
\hline Coll. $\mathrm{N}^{\mathrm{O}}$ & Sex & CS & $\mathrm{CCB}$ & Sut. Age \\
\hline FCIEN A 21 DS 4 & $\sigma^{\prime \prime}$ & 23.59 & 15.73 & 10 \\
\hline MCN 2834 & 0 & 25.18 & 15.97 & 9 \\
\hline MCN 2682 & $\sigma^{\prime}$ & 26.51 & 16.12 & 9 \\
\hline MCN 2692 & 0 & 26.88 & 16.22 & 9 \\
\hline MCN 2457 & $0^{\prime \prime}$ & 25.52 & 16.26 & 10 \\
\hline MCN 2647 & 0 & 26.94 & 16.42 & 10 \\
\hline MCN 2839 & 0 & 25.28 & 16.71 & 10 \\
\hline MCN 2702 & 0 & 26.13 & 16.77 & 9 \\
\hline UFSC 1147 & $\sigma^{\prime \prime}$ & 29.28 & 16.85 & 9 \\
\hline MCN 2500 & 0 & 27.27 & 17.02 & 9 \\
\hline UFSC 1272 & $0^{\prime \prime}$ & 29.67 & 17.23 & 10 \\
\hline MCN 2684 & $\sigma^{\prime \prime}$ & 28.69 & 17.35 & 10 \\
\hline MCN 2638 & $\sigma^{\prime \prime}$ & 27.18 & 17.57 & 10 \\
\hline MCN 2537 & 0 & 28.96 & 17.59 & 9 \\
\hline UFSC 1111 & $0^{\prime \prime}$ & 29.54 & 17.67 & 9 \\
\hline MCN 2650 & $\sigma^{\prime}$ & 26.48 & 16.46 & 12 \\
\hline MZV 435 & 0 & 25.45 & 17.1 & 10 \\
\hline UFSC 1096 & $\sigma^{\prime \prime}$ & 29.72 & 17.13 & 11 \\
\hline MCN 2634 & $0^{\prime \prime}$ & 28.37 & 17.35 & 9 \\
\hline MACN 20570 & $\sigma^{\prime \prime}$ & 26.77 & 17.4 & 11 \\
\hline UFSC 1283 & 0 & 28.33 & 17.51 & 11 \\
\hline MCN 2628 & $\sigma^{\prime \prime}$ & 26.60 & 17.84 & 13 \\
\hline UFSC 1282 & $0^{\prime \prime}$ & 27.76 & 17.89 & 11 \\
\hline MCN 2529 & 0 & 29.68 & 17.98 & 12 \\
\hline MCN 2606 & $\sigma^{\prime \prime}$ & 29.34 & 18.12 & 13 \\
\hline UFSC 1135 & $\sigma^{\prime \prime}$ & 35.67 & 22 & 8 \\
\hline UFSC 1156 & 0 & 34.22 & 22 & 18 \\
\hline UFSC 1143 & $0^{\prime \prime}$ & 36.93 & 22.2 & 19 \\
\hline UFSC 1157 & 0 & 37.28 & 22.4 & 19 \\
\hline UFSC 1153 & $\sigma^{\prime \prime}$ & 35.75 & 22.54 & 18 \\
\hline UFSC 1142 & $\sigma^{\prime \prime}$ & 38.02 & 22.7 & 19 \\
\hline UFSC 1158 & $0^{\prime \prime}$ & 39.12 & 23 & 26 \\
\hline UFSC 1163 & $\sigma^{\prime}$ & 40.79 & 23 & 29 \\
\hline UFSC 1063 & 0 & 36.64 & 23.2 & 25 \\
\hline UFSC 1160 & o' & 39.53 & 23.2 & 18 \\
\hline UFSC 1170 & 0 & 38.36 & 23.4 & 29 \\
\hline UFSC 1154 & $\sigma^{\prime \prime}$ & 37.66 & 23.5 & 20 \\
\hline UFSC 1169 & $\sigma^{\prime \prime}$ & 38.43 & 24 & 21 \\
\hline MCN 2688 & $\sigma^{\prime \prime}$ & 43.94 & 24.24 & 24 \\
\hline
\end{tabular}


FCIEN 1584

FCIEN 434

UFSC 1139

MCN 533

MCN 2694

MCN 2690

FCIEN 433

MACN 25192

MCN 1531

UFSC 1137

MCN 247

MCN 2636

UFSC 1141

MCN 2683

UFSC 1131

MCN 2639

UFSC 1040

MACN 28261

MCN 2644

MZV 1517

MCN 2625

MZV 1523

FCIEN AL961

FCIEN 1538

MCN 2523

MCN 2833

MZV 1532

MCN 2614

MZV 1552

MZV 1580

MCN 2699

FCIEN 1527

FCIEN 336

FCIEN 1529

FCIEN 1550

UFSC 1133

Callorhinus ursinus

Coll. N ${ }^{\circ}$

MZV 114107

MZV 115223

CAS 22829

CAS 2323

CAS 26753

CAS 4655

CAS 3845

MZV 115218

MZV 115224

MZV 35085

CAS 3070

CAS 3696

CAS 4656

CAS 4468

CAS 3151

CAS 545

UMICH 114794

UMICH 114793

$\mathrm{NMNH}^{*} 285726$

$\mathrm{NMNH}^{*} 285653$

$\mathrm{NMNH}^{*} 285665$

$\mathrm{NMNH}^{*} 47080$

\begin{tabular}{|c|c|c|c|c|}
\hline 오 & 18.93 & 13.19 & 9 & - \\
\hline 우 & 21.62 & 14.49 & 9 & 0 \\
\hline 우 & 24.68 & 15.11 & 9 & $\#$ \\
\hline 오 & 23.68 & 15.14 & 9 & - \\
\hline 우 & 23.18 & 15.43 & 9 & 1 \\
\hline 오 & 23.51 & 15.44 & 9 & 0 \\
\hline 오 & 23.16 & 15.57 & 12 & 0 \\
\hline Q & 23.36 & 15.73 & 9 & - \\
\hline 우 & 23.41 & 16.06 & 9 & 1 \\
\hline 오 & 24.81 & 16.11 & 10 & - \\
\hline OQ & 26.24 & 16.19 & 9 & 1 \\
\hline 오 & 26.48 & 16.4 & 10 & 0 \\
\hline 우 & 28.27 & 16.56 & 9 & - \\
\hline 우 & 25.95 & 16.9 & 9 & 1 \\
\hline 우 & 29 & 17.04 & 9 & - \\
\hline 오 & 28.07 & 16.17 & 13 & 1 \\
\hline 오 & 28.57 & 17.48 & 11 & \# \\
\hline 오 & 25.16 & 17.73 & 11 & - \\
\hline 우 & 28.51 & 17.75 & 13 & 4 \\
\hline 우 & 31.63 & 18.2 & 16 & 4 \\
\hline 오 & 27.88 & - & 12 & 2 \\
\hline 우 & 30.43 & 19.19 & 29 & - \\
\hline 우 & 33.36 & 20 & - & - \\
\hline 오 & 30.83 & 20 & 30 & 14 \\
\hline 우 & 37.36 & 20 & 28 & - \\
\hline 우 & 34.41 & 20 & 28 & 10 \\
\hline 우 & 31.61 & 20.11 & 32 & - \\
\hline 우 & 34.92 & 20.3 & 27 & 14 \\
\hline 우 & 31.59 & 20.32 & 30 & 7 \\
\hline Q & 31.07 & 20.5 & 39 & - \\
\hline 우 & 35.29 & 21.13 & 28 & 9 \\
\hline 우 & 30.91 & 21.19 & 25 & - \\
\hline 우 & 31.72 & 21.72 & 29 & 11 \\
\hline 오 & 32.07 & 21.73 & 23 & - \\
\hline & 37.01 & 24.39 & 26 & 11 \\
\hline & 35.33 & 29.54 & 19 & $\#$ \\
\hline
\end{tabular}

\begin{tabular}{l}
0 \\
\# \\
\hline \\
1 \\
0 \\
0 \\
- \\
1 \\
- \\
1 \\
0 \\
- \\
1 \\
- \\
1 \\
$\#$ \\
- \\
4 \\
4 \\
2 \\
- \\
- \\
14 \\
- \\
10 \\
- \\
14 \\
7 \\
\hline
\end{tabular}

4

10

4

1

1

$\begin{array}{lllll}\text { Sex } & \text { CS } & \text { CCB } & \text { Sut. Age } & \text { Age } \\ \sigma^{\prime \prime} & 214.542 & 12.93 & 9 & 0 \\ \sigma^{\prime \prime} & 342.167 & 19.28 & 10 & 3 \\ \sigma^{\prime \prime} & 266.568 & 13.2 & 9 & - \\ \sigma^{\prime \prime} & 254.386 & 13.55 & 9 & 0 \\ \sigma^{\prime \prime} & 269.104 & 15.37 & 9 & - \\ \sigma^{\prime \prime} & 296.989 & 16.93 & 9 & 2 \\ \sigma^{\prime \prime} & 233.996 & 19.85 & 15 & 4 \\ \sigma^{\prime \prime} & 332.438 & 18.44 & 14 & 3 \\ \sigma^{\prime \prime} & 323.052 & 19.12 & 16 & 4 \\ \sigma^{\prime \prime} & 331.588 & 18.95 & 16 & 3 \\ \sigma^{\prime \prime} & 336.563 & 17.81 & 11 & 2 \\ \sigma^{\prime \prime} & 384.514 & 19.26 & 15 & - \\ \sigma^{\prime \prime} & 371.644 & 20.83 & 14 & 5 \\ \sigma^{\prime \prime} & 404.831 & 20.71 & 15 & 4 \\ \sigma^{\prime \prime} & 469.817 & 24.65 & 20 & - \\ \sigma^{\prime \prime} & 425.393 & 28.37 & 29 & 9 \\ \sigma^{\prime \prime} & 278.803 & 18.87 & - & - \\ \sigma^{\prime \prime} & 280.559 & 18.81 & - & - \\ \sigma^{\prime \prime} & 364.135 & 23.06 & 33 & - \\ \sigma^{\prime \prime} & 387.057 & 24.04 & 28 & - \\ \sigma^{\prime \prime} & 419.181 & 25.33 & 30 & - \\ \sigma^{\prime \prime} & 405.045 & 24.98 & 19 & -\end{array}$




\begin{tabular}{|c|c|c|c|c|c|}
\hline MZV 43 & 0 & 343.644 & 24.01 & 26 & - \\
\hline $\mathrm{NMNH}^{*} 285684$ & $\sigma^{\prime \prime}$ & 398.729 & 22.07 & 31 & 2 \\
\hline $\mathrm{NMNH}^{*} 285694$ & 0 & 387.280 & 23.72 & 20 & 4 \\
\hline $\mathrm{NMNH}^{*} 285697$ & 0 & 402.634 & 23.65 & 27 & 3 \\
\hline CAS 23153 & 우 & 406.728 & 12.85 & 9 & - \\
\hline CAS 23831 & 우 & 211.166 & 13.66 & 9 & 0 \\
\hline CAS 23145 & 오 & 211.166 & 13.58 & 9 & - \\
\hline CAS 23829 & 우 & 210.265 & 13.2 & 9 & 0 \\
\hline CAS 23835 & 오 & 235.537 & 13.94 & 9 & - \\
\hline CAS 26760 & 우 & 239.410 & 14.4 & 9 & - \\
\hline CAS 23832 & 오 & 236.604 & 14.16 & 11 & 0 \\
\hline MZV 115227 & 오 & 296.393 & 16.85 & 11 & 2 \\
\hline CAS 2322 & 오 & 307.635 & 16.36 & 11 & 1 \\
\hline CAS 4185 & 오 & 293.647 & 19.58 & 12 & 3 \\
\hline CAS 4682 & 우 & 292.519 & 17.03 & 12 & - \\
\hline CAS 4235 & 오 & 296.029 & 19.51 & 23 & 5 \\
\hline CAS115228 & 우 & 304.093 & 18.01 & 23 & 7 \\
\hline CAS 21497 & 오 & 381.839 & 20.18 & 34 & - \\
\hline CAS 23101 & 우 & 306.776 & 16.59 & 24 & - \\
\hline CAS 2329 & 오 & 386.688 & 19.51 & 19 & 6 \\
\hline CAS 4564 & 우 & 370.351 & 18.73 & 18 & 7 \\
\hline CAS 1894 & 오 & 305.949 & 19.25 & 25 & 7 \\
\hline CAS 2402 & 우 & 341.551 & 19.15 & 28 & - \\
\hline CAS 3081 & 오 & 320.004 & 18.06 & 21 & 10 \\
\hline CAS21243 & 우 & 343.078 & 18.3 & 30 & - \\
\hline UAM 11492* & 오 & 290.226 & 17.92 & 20 & - \\
\hline UAM 11497* & 우 & 312.306 & 19.44 & 25 & - \\
\hline NMNH 286143* & 우 & 299.077 & 18.62 & 22 & 6 \\
\hline AMNH 3800* & 우 & 270.482 & 17.16 & 18 & - \\
\hline \multicolumn{6}{|l|}{ Otaria byronia } \\
\hline Coll. N ${ }^{\mathrm{o}}$ & Sex & CS & $\mathrm{CCB}$ & Sut. Age & Age \\
\hline FCIEN 1202 & $\sigma^{\prime}$ & 220.856 & 15.11 & 9 & 0 \\
\hline CNP 115 & 0 & 257.928 & 15.49 & 9 & 0 \\
\hline MACN 30236 & $\sigma^{\prime}$ & 246.002 & 16.88 & 9 & - \\
\hline LAMAMA 62 & $\sigma^{\prime \prime}$ & 236.171 & 17.16 & 9 & - \\
\hline LAMAMA 115 & $\sigma^{\prime \prime}$ & 243.689 & 17.55 & 9 & 0 \\
\hline LAMAMA 134 & $0^{\prime \prime}$ & 274.455 & 18.43 & 10 & 0 \\
\hline MACN 125 & o' & 295.501 & 21.14 & 9 & - \\
\hline MACN 20595 & o' & 309.940 & 22.23 & 14 & 2 \\
\hline LAMAMA 555 & $\sigma^{\prime \prime}$ & 332.540 & 23.95 & - & - \\
\hline LAMAMA 31 & $0^{\prime \prime}$ & 358.622 & 24.73 & 14 & 3 \\
\hline MACN50.52 & 0 & 363.366 & 24.85 & 13 & 3 \\
\hline LAMAMA 24 & $\sigma^{\prime \prime}$ & 356.799 & 25.05 & 13 & 2 \\
\hline CENPAT 160 & $0^{\prime \prime}$ & 364.590 & 25.24 & 16 & - \\
\hline MCN 2610 & 0 & 462.272 & 25.88 & 15 & 5 \\
\hline MACN 21743 & 0 & 364.699 & 26.1 & 15 & - \\
\hline LAMAMA 487 & 0 & 397.021 & 26.21 & 17 & - \\
\hline LAMAMA 105 & $\sigma^{\prime \prime}$ & 352.305 & 26.32 & 15 & 5 \\
\hline UFSC 1161 & $\sigma^{\prime \prime}$ & 375.044 & 26.43 & 13 & 2 \\
\hline LAMAMA 270 & $0^{\prime \prime}$ & 355.093 & 26.55 & 14 & 0 \\
\hline LAMAMA 43 & 0 & 400.319 & 26.86 & 15 & 5 \\
\hline MACN 25.45 & $\sigma^{\prime \prime}$ & 403.084 & 27.15 & 15 & 4 \\
\hline MCN 2525 & $0^{\prime \prime}$ & 427.622 & 27.35 & 14 & 5 \\
\hline UFSC 1168 & $0^{\prime \prime}$ & 395.835 & 28.64 & 15 & 2 \\
\hline MACN 20420 & 0 & 447.971 & 29.29 & 15 & 4 \\
\hline LAMAMA 337 & $\sigma^{\prime}$ & 412.758 & 29.69 & 15 & 7 \\
\hline GEMARS 667 & 0 & 540.036 & 32 & 17 & - \\
\hline LAMAMA 90 & $0^{\prime \prime}$ & 329.387 & 25.73 & 22 & 3 \\
\hline UFSC1152 & $0^{\prime \prime}$ & 379.361 & 26.56 & 15 & 1 \\
\hline MZV 28 & $\sigma$ & 525.993 & 29.67 & 23 & 7 \\
\hline
\end{tabular}




\begin{tabular}{|c|c|c|c|c|c|}
\hline LAMAMA 60 & 0 & 412.408 & 30.49 & 20 & 6 \\
\hline MACN 20583 & $\sigma^{\prime \prime}$ & 542.353 & 30.98 & 26 & 8 \\
\hline MZV 87001 & 0 & 571.605 & 31.88 & 36 & - \\
\hline LAMAQ 1134 & $\sigma$ & 497.132 & 31.9 & 23 & - \\
\hline LAMAQ 1140 & $\sigma^{\prime \prime}$ & 479.440 & 32 & 21 & 7 \\
\hline MCN 2990 & $\sigma^{\prime}$ & 552.200 & 32.27 & 33 & 9 \\
\hline MACN 41226 & 0 & 478.253 & 32.4 & 26 & - \\
\hline GEMARS 171 & 0 & 532.548 & 32.45 & 36 & \# \\
\hline GEMARS 353 & $\sigma^{\prime \prime}$ & 524.341 & 32.52 & 26 & \# \\
\hline MCN 2505 & $\sigma^{\prime}$ & 558.594 & 32.95 & 20 & 7 \\
\hline MCN 2696 & 0 & 569.611 & 33.15 & 27 & 6 \\
\hline MZV 1181 & $\sigma$ & 543.199 & 33.43 & 21 & 9 \\
\hline UFSC 1171 & $\sigma^{\circ}$ & 538.996 & 33.5 & 36 & - \\
\hline MCN 2460 & $\sigma$ & 576.586 & 33.58 & 30 & 14 \\
\hline GEMARS 284 & 0 & 519.106 & 33.84 & 30 & \# \\
\hline MACN 20168 & $\sigma^{\prime \prime}$ & 446.280 & 34.34 & 32 & - \\
\hline GEMARS 658 & $0^{\circ}$ & 543.883 & 34.39 & 31 & - \\
\hline CENPAT 111 & 오 & 158.295 & 9.98 & 9 & 0 \\
\hline MACN 21740 & 오 & 230.889 & 14.99 & 9 & 0 \\
\hline LAMAMA 70 & 오 & 250.979 & 16.53 & 9 & 0 \\
\hline MACN 21737 & 우 & 322.395 & 20.69 & 17 & - \\
\hline MACN 21741 & 오 & 148.127 & 9.58 & 9 & 0 \\
\hline MACN 10.30 & 오 & 157.847 & 12.21 & 9 & 0 \\
\hline LAMAMA 237 & 우 & 297.321 & 20.89 & 12 & 2 \\
\hline FCIEN 1196 & 우 & 282.251 & 22.4 & 15 & - \\
\hline LAMAMA 483 & 오 & 338.476 & 22.59 & 16 & - \\
\hline MACN 21738 & 우 & 337.451 & 22.69 & 16 & - \\
\hline LAMAMA 240 & 우 & 316.188 & 22.89 & 15 & 3 \\
\hline FCIEN 332 & 오 & 335.863 & 22.9 & 15 & 3 \\
\hline LAMAMA 243 & 우 & 339.389 & 23.44 & 15 & 7 \\
\hline LAMAMA 127 & 우 & 326.419 & 23.94 & 16 & 6 \\
\hline LAMAMA 251 & 우 & 326.602 & 24.12 & 16 & - \\
\hline LAMAMA 33 & 오 & 340.558 & 24.21 & 15 & 6 \\
\hline LAMAMA 536 & 오 & 330.940 & 25.25 & 15 & - \\
\hline LAMAMA 303 & 오 & 367.634 & 25.32 & 17 & 3 \\
\hline MACN 20573 & 우 & 340.015 & 25.33 & 15 & - \\
\hline MCN-M 2691 & 오 & 446.209 & 25.5 & 17 & 7 \\
\hline LAMAMA 61 & 오 & 371.000 & 25.12 & 29 & 10 \\
\hline MACN 25138 & 우 & 335.881 & 25.28 & 23 & 5 \\
\hline MACN 90.03 & 우 & 392.383 & 25.33 & 23 & 11 \\
\hline LAMAMA 478 & 오 & 351.266 & 25.34 & - & - \\
\hline MACN 20578 & 우 & 367.904 & 25.67 & 23 & - \\
\hline LAMAMA 89 & 우 & 377.546 & 25.83 & 30 & - \\
\hline LAMAMA 88 & 우 & 369.004 & 25.87 & 29 & 10 \\
\hline MCN 2701 & 우 & 449.707 & 25.96 & 22 & 8 \\
\hline MACN 20576 & 우 & 375.854 & 26.31 & 27 & - \\
\hline MACN 20596 & 오 & 443.583 & 26.7 & 28 & 12 \\
\hline MCN 2462 & 우 & 385.647 & 26.9 & 20 & 13 \\
\hline MCN 2703 & 오 & 470.011 & 27.48 & 24 & 9 \\
\hline MACN 13.11 & 오 & 409.025 & 27.8 & 27 & 9 \\
\hline MZV 1188 & 우 & 465.070 & 30.48 & 17 & 11 \\
\hline MACN 20572 & 오 & 352.886 & 26.75 & 29 & - \\
\hline GEMARS 428 & o & 533.254 & 33.53 & 36 & $\#$ \\
\hline
\end{tabular}




\section{APPENDIX 2}

\section{ANATOMICAL DESCRIPTION OF THE LANDMARKS}

1 Anteriormost point of the pre-maxilla tuberosity

2 Antero-lateral extremity of third incisive alveolus

3 Anteriormost point of incisive foramen

4 Lateral extremity of canine alveolus

5 Anteromedial point of first post-canine alveolus

6 Anteriormost point of the maxilla-palatine suture

7 Point that label the direction change of the maxilla-palatine suture

8 Posteriormost point of the root at the lateral limit at bone palate of zigomatic process of the maxilla

9 Posteriormost point of sixth post-canine alveolus

10 Posteriormost point of palatine extension of maxilla ("pterygoid" process of the maxilla)

11 Posteriormost point of interpalatine suture

12 Point that label the direction change of the posterior border of palatine

13 Posteriormost extremity of oval foramen

14 Lateral extremity of jugal-esquamosal suture

15 Medial extremity of the contact between the glenoid fossa and the ectotympanic

16 Anteriormost extremity of the anterior aperture of carotid canal

17 Antero-lateral corner of mastoid process

18 Posteriormost point of the condiloid foramen

19 Posteriormost point of occipital condyle

20 Anteriormost point of foramen magnum 